\title{
Potential of Green Chili Extract (Capsicum annuum) on myeloma cells death
}

\author{
$\underline{\text { Rochmah Kurnijasanti }}^{1, a)^{*}}$, Alifvia Izza Putri Edward ${ }^{2(\mathrm{~b})}$, Yonas Kristijanto ${ }^{3}$, \\ Doohan Mahendra ${ }^{4}$, and Nadya Ivanora Hermanda ${ }^{5}$ \\ 1,2,3,4,5 Department of Basic Medicine Veterinary, Veterinary Faculty, Airlangga \\ University ${ }^{a}$ Corresponding author: \\ santisam19@yahoo.co.id \\ b)vyalif.putri@gmail.com
}

\begin{abstract}
The purpose of the study was to determine the potential of the ethanol extract of green chili (Capsicum annum) against the proliferation of myeloma cells. The study used ethanol extract of green chili (Capsicum annum) by maceration. The Myeloma cell concentration was $1.10^{-5}$ $\mathrm{ml}^{-1}$ of medium DMEM and 10\% FBS. The treatment of Myeloma cells were divided into 8 treatments with 5 repetitions. The treatment group was treated with the extract of green chili concentration of $1 \%, 2 \%, 4 \%, 8 \%, 16 \%, 32 \%$, and $64 \%$ by administration of $0.1 \mathrm{ml}$ each microplate, while the control group was treated without the extract of green chili but using aqua pro injection of a placebo substance. Once it is stored into a cooler with $\mathrm{CO} 2$ because myeloma cells require $\mathrm{CO} 2$ to live, and its growth was observed for 3 days. Observations were made in three days post treatment using miscroscope by observing myeloma living cells, lysis, and dead cells after the addition of extracts of green chili. Data were analyzed descriptively. The results showed that green chili extract concentration could inhibit proliferation of myeloma cells. In the treatment granting extract of green chili of $64 \%$ concentration caused $100 \%$ myeloma cells die.
\end{abstract}

Keywords: Extract, Green chili, Capsicum annum, Proliferation, Myeloma cells death.

\section{INTRODUCTION}

Cancer is an abnormal cycle of the cell disease that result uncontrollable cell growth (abnormal cell division) that attack surrounding tissue and migrate to other body tissues via the blood vessel and lymphatic system (cells metastases) (NCI, 2011). Cancer is one of the leading causes of death worldwide. In 2012, about 8.2 million deaths caused by cancer. More than $60 \%$ of new cases and approximately $70 \%$ of cancer deaths in the world each year occur in Africa, Asia and Central and South America. It is estimated that the annual cancer cases will increase from 14 million in 2012 to 22 million in the next two decades (Jemal et al., 2005). Nationally, the prevalence of cancer in the population of all ages in Indonesia in 2013 was $1.4 \%$ or estimated around 347 to 792 people. Treatment for cancer is quite expensive, especially for developing countries like Indonesia with most cases of cancer patients. From the economic side, the state expenditures for cancer are the second highest after expenditures for haemodialysis. State expenditures for cancer in 2012 reached 144.7 billion (Riset Kesehatan Dasar, 2013).

Conventional treatment of common disease among cancer with surgery, chemotherapy and radiotherapy (Apantaku, 2002). Therapeutic cancer surgery cannot be done, especially in the case that cancer cells have spread (metastases). Although chemotherapy can kill cancer cells, chemotherapy and radiation can cause side effects (Ixora, 
2007). The treatment of cancer is still developed to reduce the side effects of treatment. Many studies conducted to obtain an anti-cancer active ingredient with less side effects and affordable (Sukmarianti, 2013). The use of herbs developed for cancer therapy is possible because the effect is smaller, especially in Indonesia. Indonesia is an agricultural country. One food that is produced is chili. In general, the public only knows the use of chili for seasoning. The chili has the effect of a very spicy taste and as a food flavour enhancer. Chili contains vitamins A, B, C, D, E, and minerals, which act as antioxidants. The highest antioxidant content is in green chili. In addition to antioxidants, chili also contains $L$ asparaginase and Capsaicin. L-asparaginase compounds and capsaicin in chili serves to control cancer (Kilham 2006). Based on this background, it is necessary to do research on the potential of green chilli extract.

\section{RESEARCH METHODS}

The study was an experimental laboratory research using Myeloma cancer cultures. The study was conducted at the Laboratory of Pharmacology of the Faculty of Veterinary Medicine and Laboratory Pusvetma Airlangga University Surabaya.

\section{Research Tools}

The tools used in the study were test tube, conical tube, measuring cups, micro pipette, yellow tip, eppendorf, syringe $(1 \mathrm{ml})$, glass beaker, erlenmeyer, plate 24 wells, petri dish, cover glass, objects glass, analytical balance, rotary evaporator (Buchi), vortex, centrifuges, refrigerators, Laminar Air Flow, and a microscope.

\section{Research Materials}

Materials used in this study include: myeloma cell culture, green chili (Capsicum annum), absolute ethanol (96\%), distilled sterile water, Fetal Bovine Serum (FBS) 10\%, DMEM Medium.

\section{Procedure Extract}

The extract of green chili was made using maceration method. First, green chili was dried in a room temperature then made into powder. Second, the powder was macerated in $96 \%$ ethanol for three days. Furthermore, the macerate was obtained by filtering and evaporating using rotary evaporator to get thick extract.

\section{In Vitro Anticancer test using Myeloma Cells}

Myeloma cells were thawed and propagated in petri dish until the cell is ready for test. Myeloma cells $10^{5}$ cells $\mathrm{ml}^{-1}$ in $2 \mathrm{ml}$ of cell medium (DMEM and FBS 10\%) were included in 24 well plate and added with test samples that have been dissolved in sterile distilled water with a concentration of respectively $0 \%$ (control), $1 \%, 2 \%, 4 \%, 8 \%, 16 \%$, $32 \%$ and $64 \%$ of $100 \mathrm{~mL} /$ well. Each concentration be repeated 3 times. Furthermore it was incubated at a temperature of $37 \square \mathrm{C}$ for 24 hours. The living cells, lysis and death was observed using microscope. 


\section{RESULT AND DISCUSSION}

The result of Myeloma cell growth observation in each concentration is presented on Figure 1.

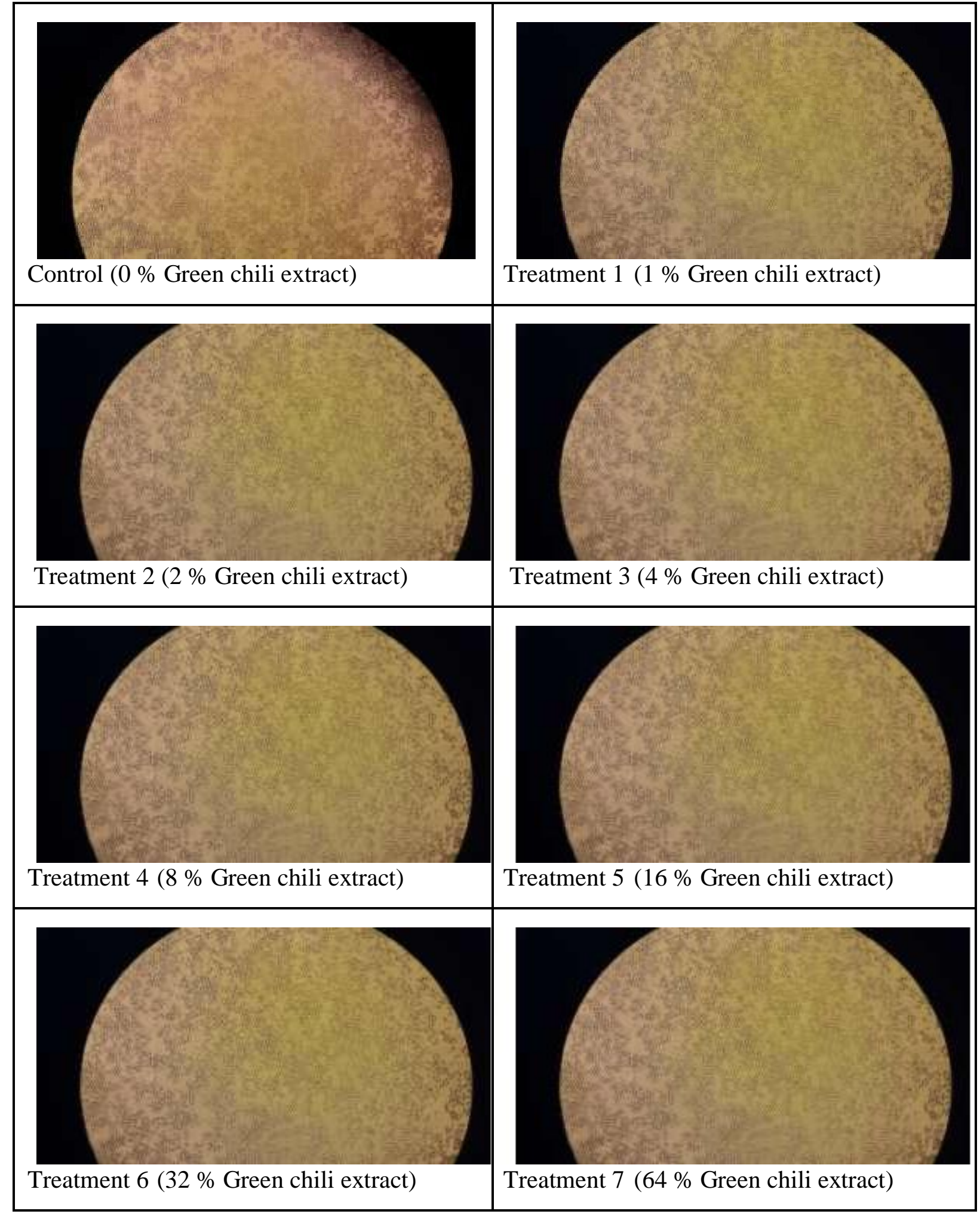

Figure 1. Observations myeloma cell culture with various treatments green chili Extracts (Capsicum annuum) using a microscope with 200x magnification. 